\title{
PHENOMENA ERA GOJEK
}

\author{
HENGKY RONALDO \\ 165100059 \\ Fakultas Komputer \\ Hengkyronaldo.student@umitra.ac.id
}

\begin{abstract}
Teknologi tidak bisa dipungkiri telah membawa banyak perubahan di peta persaingan bisnis saat ini. Mulai dari lahirnya pesaing-pesaing baru, inovasiinovasi produk baru, sampai hadirnya berbagai model bisnis baru yang berbasis teknologi.

Berbicara mengenai persaingan bisnis, saat ini bukan hanya berbicara mengenai kompetisis bisnis dalam negeri, tetapi juga persaingan dengan kompetitor luar negeri yang berawal dari Masyarakat Ekonomi Asean (MEA) yang dimulai awal 2016 ini. Teknologi tidak bisa dipungkiri telah membawa banyak perubahan di peta persaingan bisnis saat ini. Mulai dari lahirnya pesaing-pesaing baru, inovasi-inovasi produk baru, sampai hadirnya berbagai model bisnis baru yang berbasis teknologi.
\end{abstract}

Berbicara mengenai persaingan bisnis, saat ini bukan hanya berbicara mengenai kompetisis bisnis dalam negeri, tetapi juga persaingan dengan kompetitor luar negeri yang berawal dari Masyarakat Ekonomi Asean (MEA) yang dimulai awal 2016 ini.

Kata Kunci : Gojek, Kontribusi social, Tukang ojek, Ride sharing

A. PENDAHULUAN

Perkembangan teknologi

memaksa manusia untuk

berubah. Satu decade

terakhir masyarakat

memulai membiasakan diri

dengan semakin masifnya perkembangan teknologi.
Kemunculan internet yang kemudian di ikuti dengan kemajuan dan kemudahan alat komunikasi telah mengubah pandangan manusia tentang teknologi. Revolusi teknologi di mulai dari era di perkenalkanya 
internet yang kemudian telah mengubah prilaku manusia menjadi lebih kritis dan sensitive terhadap perubahan rasa dan selera di mana pada akhirnya mengubah seluruh tatanan kehidupan (irianto, 2015).

B. PEMBAHASAN / STUDI KASUS

Gojek adalah sebuah industry ride-sharing terdiri atas berbagai actor yang berpengaruh dalam kelangsungan proses bisnis. Industry yang menggunakan model berbasis aplikasi internet ini terdiri atas perusahaan gojek yang memiliki sistem, driver gojek, konsumen, berbagai peralatan seperti aplikasi, gadget, sepedah motor, dan berbagai symbol indentitas perusahaan.berbagai actor tersebut Saling berkaitan dalam kelangsungan proses bisnis gojek

C. ID SECURITY

QWTD4452377-ASP5244107

D. KESIMPULAN

Perkembangan teknologi informasi dan penetrasi jaringan internet mendorong tumbuhnya industry digital yang menyasar konsumen pemilik telepon pintar. Industry digital tumbuh pesat didukung oleh platform sistem terbuka (android) yang bias dikembangkan untuk berbagai aplikasi yang di sesuaikan dengan kebutuhan pengembang dan masyrakat. Salah satu bisnis startup yang berkembang adalah penyediaan aplikasi ride sharing yang mempertemukan driverpassanger dengan cara baru yang lebih cepat, aman dan murah. Di dahului dengan heboh aplikasi uber yang merupakan versi taxi online, disusul dengan aplikasi grab (bike/car) hingga yang sangat terkenal di Indonesia gojek.

\section{E. DISKUSI}

Hasil diskusi saya dengan teman saya adalah pembahasan ini terkait dengan era gojek ini memberikan pemahaman yang luas terkait dengan sistem oprasional gojek. Gojek menyasar konsumen kota-kota besar di Indonesia yang sangat besar di Indonesia yang sangat peka dengan masalah transportasi. Gojek meberikan solusi terkait dengan penyediaan transportasi umum yang cepat, aman dan murah berbasis aplikasi yang bias di unduh memlalui plasytore (android) maupun playstore (ios). 


\section{F. REFERENCE}

[1] O. M. Febriani and A. S. Putra, "Sistem Informasi Monitoring Inventori Barang Pada Balai Riset Standardisasi Industri Bandar Lampung," J. Inform., vol. 13 , no. 1 , pp. 90-98, 2014.

[2] A. S. Putra, "Paperplain: Execution Fundamental Create Application With Borland Delphi 7.0 University Of Mitra Indonesia," 2018.

[3] A. S. Putra, "2018 Artikel Struktur Data, Audit Dan Jaringan Komputer," 2018.

[4] A. S. Putra, "ALIAS MANAGER USED IN DATABASE DESKTOP STUDI CASE DB DEMOS."

[5] A. S. Putra, "COMPREHENSIVE SET OF PROFESSIONAL FOR DISTRIBUTE COMPUTING."

[6] A. S. Putra, "DATA ORIENTED RECOGNITION IN BORLAND DELPHI 7.0."

[7] A. S. Putra, "EMBARCADERO DELPHI XE 2 IN GPUPOWERED FIREMONKEY APPLICATION."

[8] A. S. Putra, "HAK ATAS KEKAYAAN INTELEKTUAL DALAM DUNIA TEKNOLOGY BERBASIS REVOLUSI INDUSTRI 4.0."

[9] A. S. Putra, "IMPLEMENTASI PERATURAN 
PERUNDANGAN UU. NO 31 TAHUN 2000 TENTANG DESAIN INDUSTRI BERBASIS INFORMATION TECHNOLOGY."

[10] A. S. Putra, "IMPLEMENTATION OF PARADOX DBASE."

[11] A. S. Putra, "IMPLEMENTATION OF TRADE SECRET CASE STUDY SAMSUNG MOBILE PHONE."

[12] A. S. Putra, "IMPLEMENTATION PATENT FOR APPLICATION WEB BASED CASE STUDI WWW. PUBLIKLAMPUNG. COM."

[13] A. Putra "IMPLEMENTATION SYSTEM FIRST TO INVENT IN DIGITALLY INDUSTRY."

[14] A. S. Putra, "MANUAL REPORT \& INTEGRATED DEVELOPMENT ENVIRONMENT BORLAND DELPHI 7.0."

[15] A. S. Putra, "PATENT AS RELEVAN SUPPORT RESEARCH."

[16] A. S. Putra, "PATENT FOR RESEARCH STUDY CASE OF APPLE. Inc."

[17] A. S. Putra, "PATENT PROTECTION FOR APPLICATION INVENT."

[18] A. S. Putra, "QUICK REPORT IN PROPERTY PROGRAMMING."

[19] A. S. Putra, "REVIEW CIRCUIT LAYOUT COMPONENT REQUIREMENT ON ASUS NOTEBOOK."

[20] A. S. Putra, "REVIEW TRADEMARK PATENT FOR INDUSTRIAL TECHNOLOGY
BASED 4.0."

[21] A. S. Putra, "TOOLBAR COMPONENT PALLETTE IN OBJECT ORIENTED PROGRAMMING."

[22] A. S. Putra, "WORKING DIRECTORY SET FOR PARADOX 7."

[23] A. S. Putra, "ZQUERY CONNECTION

IMPLEMENTED

PROGRAMMING STUDI CASE PT. BANK BCA Tbk."

[24] A. S. Putra, D. R. Aryanti, and I. Hartati, "Metode SAW (Simple Additive Weighting) sebagai Sistem Pendukung Keputusan Guru Berprestasi (Studi Kasus: SMK Global Surya)," in Prosiding Seminar Nasional Darmajaya, 2018, vol. 1, no. 1, pp. 85-97.

[25] A. S. Putra and O. M. Febriani, "Knowledge Management Online Application in PDAM Lampung Province," in Prosiding International conference on Information Technology and Business (ICITB), 2018, pp. 181-187.

[26] A. S. Putra, O. M. Febriani, and B. Bachry, "Implementasi Genetic Fuzzy System Untuk Mengidentifikasi Hasil Curian Kendaraan Bermotor Di Polda Lampung," SIMADA (Jurnal Sist. Inf. dan Manaj. Basis Data), vol. 1, no. 1, pp. 21-30, 2018.

[27] A. S. Putra, H. Sukri, and K. Zuhri, "Sistem Monitoring Realtime Jaringan Irigasi Desa (JIDES) Dengan Konsep Jaringan Sensor Nirkabel," IJEIS (Indonesian J. 
Electron. Instrum. Syst., vol.

8, no. 2, pp. 221-232.

[28] D. P. Sari, O. M. Febriani, and

A. S. Putra, "Perancangan

Sistem Informasi SDM

Berprestasi pada SD Global

Surya," in Prosiding Seminar

Nasional Darmajaya, 2018,

vol. 1, no. 1, pp. 289-294. 